\title{
ANALISIS FRAKSI AKTIF EKSTRAK DAUN GEDI HIJAU (Abelmoschus manihot L.) DALAM MENANGKAL RADIKAL BEBAS DPPH
}

\author{
Maria Tilda Atuani' ${ }^{1)}$, Sri Sudewi ${ }^{1)}$, Defny S. Wewengkang ${ }^{1)}$ \\ Program Studi Farmasi FMIPA UNSRAT Manado, 95115
}

\begin{abstract}
Gedi (Abelmoschus manihot L.) is a tropical plant of family malvaceae, traditionally known in North Sulawesi as a vegetable plant. Gren gedi leaves from Bitung are known to have activity as free radical scavenging at extract level but have not been tested at the fraction level. This study aims to determine the free radical scavenging activity of the green gedi leaf fractions in counteraction DPPH (1,1-diphenil-2picrylhydarzyl) free radical. Extraction was done by maceration method using ethanol solvent. The preliminary test of free radical scavenging was carried out by thin layer chromatography (TLC) using the stationary phase of silica gel $F_{254}$ with the mobile phase of n-hexane : chloroform (1:2) and sprayed with DPPH 0,08 $\mathrm{mM}$. Then it was fractionated using vacuum liquid chromatography $(V L C)$ with the mobile phase based on its polarity, such as combination of n-hexane and ethyl acetate. Each fraction obtained was tested for free radical scavenging activity showed whitish yellow patches on a purple background, which indicates that extracts have free radical scavenging activity. The spectrophotometer measurement results showed that each leaf of green gedi leaves had weak free radical scavenging activity, but still was a free radical scavenger, ie fraction $I$ had an $I_{50}$ value of 169,69 $\mu \mathrm{g} / \mathrm{mL}$; fraction II was 826,52 $\mu \mathrm{g} / \mathrm{mL}$; fraction III was 311,13 $\mu \mathrm{g} / \mathrm{mL}$; and fraction IV was $246,80 \mu \mathrm{g} / \mathrm{mL}$. Fraction $V$ has an $I C_{50}$ value of 2294,64 $\mu \mathrm{g} / \mathrm{mL}$, this is indicates that the fraction $V$ has no activity as a free radical scavenging compound, because it has very large $I C_{50}$ value. While vitamin $C$ as a comparison has very strong free radical scavenging activity with $I C_{50}$ of $3,22 \mu \mathrm{g} / \mathrm{mL}$.
\end{abstract}

Keywords: Fraction, Extract, Abelmoschus manihot L., DPPH Method.

\begin{abstract}
ABSTRAK
Gedi (Abelmoschus manihot L.) merupakan tumbuhan tropis family malvaceae, secara tradisional telah lama dikenal di Sulawesi Utara sebagai tanaman sayuran. Daun gedi hijau yang berasal dari Bitung diketahui memiliki aktivitas sebagai penangkap radikal bebas pada tingkat ekstrak namun belum diuji pada tingkat fraksi. Penelitian ini bertujuan untuk mengetahui aktivitas penangkap radikal bebas dari fraksi-fraksi daun gedi hijau dalam menangkal radikal bebas DPPH (1,1-diphenil-2-picrylhydarzyl). Ekstraksi dilakukan dengan metode maserasi menggunakan pelarut etanol. Uji pendahuluan aktivitas penangkap radikal bebas dilakukan secara kromatografi lapis tipis (KLT) menggunakan fase diam silika gel $\mathrm{F}_{254}$ dengan fase gerak n-heksana : kloroform (1:2) dan disemprot DPPH 0,08mM. Kemudian difraksinasi menggunakan kromatografi cair vakum (KCV) dengan fase gerak berdasarkan kepolarannya, yakni kombinasi n-heksana dan etil asetat. Hasil uji pendahuluan aktivitas penangkap radikal bebas secara KLT menunjukkan adanya bercak kuning keputih-putihan dengan latar belakang ungu, yang menandakan ekstrak memiliki aktivitas penangkap radikal bebas. Hasil pengukuran secara spektrofotometer menunjukkan bahwa setiap fraksi daun gedi hijau memiliki aktivitas penangkap radikal bebas yang lemah, namun tetap bersifat sebagai penangkap radikal bebas, yakni fraksi I memiliki nilai $\mathrm{IC}_{50}$ sebesar $169,69 \mu \mathrm{g} / \mathrm{mL}$; fraksi II 826,52 $\mu \mathrm{g} / \mathrm{mL}$; fraksi III 311,13 $\mu \mathrm{g} / \mathrm{mL}$; dan fraksi IV 246,80 $\mu \mathrm{g} / \mathrm{mL}$. Fraksi V memiliki nilai $\mathrm{IC}_{50}$ sebesar $2294,64 \mu \mathrm{g} / \mathrm{mL}$, menandakan fraksi $\mathrm{V}$ tidak memiliki aktivitas sebagai senyawa penangkap radikal bebas, karena memiliki nilai $\mathrm{IC}_{50}$ yang sangat besar. Sedangkan vitamin $\mathrm{C}$ sebagai pembanding memiliki aktivitas penangkap radikal bebas sangat kuat dengan $\mathrm{IC}_{50}$ sebesar $3,22 \mu \mathrm{g} / \mathrm{mL}$.
\end{abstract}

Kata Kunci : Fraksi, Ekstrak, Abelmoschus manihot L., Metode DPPH. 


\section{PENDAHULUAN}

Gedi (Abelmoschus manihot L.) merupakan tumbuhan tropis family malvaceae, secara tradisional telah lama dikenal di Sulawesi Utara sebagai tanaman sayuran. Masyarakat mengenal dua jenis (Abelmoschus manihot L.), yaitu gedi merah dan gedi hijau. Daun gedi hijau dapat dimanfaatkan oleh masyarakat Manado sebagai bahan makanan yang dikenal sebagai Bubur Manado (Tinutuan) khas dari Manado, sedangkan untuk gedi merah secara tradisional dapat menyembuhkan beberapa penyakit (Mamahit dan Soekarno, 2010).

Kemampuan ekstrak daun gedi dalam menangkap radikal bebas juga dilakukan oleh Sudewi et al (2017), aktivitas penangkap radikal bebas didaerah Bitung sebesar $(23,823 \%)$, dan kandungan total fenol dan flavonoid masing-masing sebesar 22,38 mGAE/g dan 89,640 mg/g QE. Senyawa flavonoid mempunyai berbagai fungsi penting untuk kesehatan, antara lain dalam menurunkan risiko serangan penyakit kardiovaskuler, tekanan darah, aterosklerosis, dan sebagai antioksidan (Hodgson et al., 2006).

DPPH (1,1-diphenil-2-picrylhydarzyl) adalah suatu senyawa organik yang mengandung nitrogen tidak stabil dengan absorbansi kuat pada panjang gelombang 517 $\mathrm{nm}$ dan berwarna ungu gelap. DPPH telah digunakan secara luas untuk mengukur kemampuan suatu senyawa untuk menghambat radikal bebas atau sebagai pendonor hydrogen (Burda and Oleszek, 2001). Kendala pemanfaatan ekstrak kasar seperti kandungan padatan yang tinggi, aktivitas rendah serta sifat toksik perlu diwaspadai. Oleh karena itu, perlu dilakukan proses fraksinasi. Fraksinasi merupakan teknik pemisahan dan pengelompokan kandungan kimia ekstrak berdasarkan kepolaran.

\section{METODE PENELITIAN}

Alat

Alat-alat yang digunakan dalam penelitian ini adalah timbangan analitik (KERN AC $22-$ 4M), Spektrofotometer UV-Vis, (Shimadzu 00780), Komputer pengola data (Acer Aspie ES 11), lampu UV 254 dan $366 \mathrm{~nm}$, peralatan Kromatografi Cair Vakum (KCV), Vortex Mixer (Hwashin), Oven (Ecocell), Blender (Phillips), dan alat-alat gelas (pirex).

\section{Bahan}

Bahan-bahan yang digunakan dalam penelitian ini adalah Simplisia Kering daun Gedi Hijau, etanol 96\%, etil asetat, dan nheksana berderajat teknis (General Labora, Indonesia), kloroform, n-heksana dan methanol berderajat pro analisis (E. Merck), Vitamin C pro analisis, Plat KLT silika gel $60 \mathrm{GF}_{254}$ (E. Merck), silika gel $60 \mathrm{~F}_{254}$ (E. Merck) dan 1,1diphenil-2-picrylhydarzyl (DPPH) (Aldrich).

\section{Prosedur Kerja \\ Pengambilan Sampel}

Sampel daun Gedi Hijau diambil dari kota bitung, selanjutnya dibersihkan kemudian di potong kecil-kecil, lalu dikering anginkan. Daun yang telah kering dihaluskan dengan cara diblender, kemudian diayak dengan menggunakan ayakan 60 mesh sehingga diperoleh simplisia daun gedi.

\section{Ekstraksi}

Sebanyak $\quad 250$ g simplisia kering dimasukkan ke dalam bejana maserasi dan ditambahkan pelarut etanol $800 \mathrm{~mL}$ sampai semua sampel terendam oleh pelarut. Ekstraksi dilakukan dengan cara maserasi selama $3 \times 24$ 
jam dengan beberapa kali pengocokan. Ekstrak hasil maserasi kemudian disaring sehingga diperoleh filtrat dan residu. Filtrat yang diperoleh kemudian dievaporasi pada suhu $40^{\circ} \mathrm{C}$ sampai diperoleh ekstrak kental.

\section{Uji Pendahuluan Aktivitas Penangkap} Radikal Bebas

Uji pendahuluan di awali dengan memanaskan plat KLT pada oven dengan suhu $105^{\circ} \mathrm{C}$ selama 10 menit. Fase diam yang digunakan adalah silika gel $\mathrm{F}_{254}$ dengan luas $1 \mathrm{x}$ $10 \mathrm{~cm}$ dengan jarak elusi $8 \mathrm{~cm}$. Fase gerak yang digunakan untuk mengelusi yaitu, nheksana:kloroform p.a (1:2) sebanyak $2 \mathrm{~mL}$. Bercak yang terbentuk diamati dengan sinar tampak, lampu UV 254 dan $366 \mathrm{~nm}$, kemudian disemprotkan dengan larutan DPPH 0,08 mM.

\section{Fraksinasi}

Sebanyak 2 g ekstrak yang dihasilkan difraksinasi dengan metode Kromatografi Cair Vakum (KCV). Ekstrak sebanyak $2 \mathrm{~g}$ dilarutkan dengan pelarut kloroform p.a dan diimpregnasikan dengan silika gel $4 \mathrm{~g}$ sampai menjadi serbuk kering. Kolom kemudian diisi dengan serbuk fase diam silika gel sebanyak 12 g sambil divakum. Serbuk sampel kemudian ditaburkan diatasnya kemudian permukaannya ditutup lagi dengan kertas saring. Elusi dilakukan dengan fase gerak n-heksana:etil asetat dengan total volume $100 \mathrm{~mL}$, yakni pelarut n-heksana 100\% (F1), 9:1 (F2), 8:2 (F3), 7:3 (F4), 6:4 (F5), 1:1 (F6), 4:6 (F7), 3:7 (F8), 2:8 (F9), 1:9 (F10), 100\% etil asetat (F11) sambil divakum. Hasil fraksinasi kemudian dikeringkan, selanjutnya diuji secara KLT untuk melihat pola spot atau bercaknya disemprot dengan DPPH 0,08 mM. Fraksifraksi yang terbentuk dikumpulkan berdasarkan noda yang terbentuk dan nilai $\mathrm{Rf}$ yang diperoleh.

\section{Uji Aktivitas Penangkap Radikal Bebas Metode DPPH}

\section{Pembuatan Larutan DPPH 0,08 mM}

Serbuk DPPH ditimbang sebanyak 3,154 mg, kemudian dimasukkan kedalam labu ukur $100 \mathrm{~mL}$ dan dilarutkan dengan metanol p.a hingga mencapai tanda batas.

\section{Penentuan Panjang Gelombang Maksimum DPPH}

Larutan DPPH 0,08 mM sebanyak $2 \mathrm{~mL}$ dimasukkan kedalam tabung reaksi, lalu ditambahkan dengan $1 \mathrm{~mL}$ metanol p.a. Campuran DPPH kemudian divorteks dan diinkubasi pada suhu kamar selama 30 menit dalam keadaan gelap. Larutan tersebut kemudian diukur dengan spektrofotometer UVVis pada panjang gelombang 400-800 nm dengan blanko metanol p.a.

\section{Pembuatan Larutan Fraksi dan Pembanding}

Masing-masing fraksi dan pembanding vitamin C dibuat larutan induk konsentrasi $1000 \mathrm{ppm}$. Ditimbang $10 \mathrm{mg}$ fraksi, dilarutkan dengan metanol p.a lalu dimasukkan kedalam labu ukur $10 \mathrm{~mL}$, volume ditambahkan dengan metanol p.a sampai tanda batas. Kemudian dibuat seri konsentrasi masing-masing, yaitu 15, 30, 60, dan 120 ppm untuk fraksi dan 2, 4, 6, dan 8 ppm untuk vitamin C. Masing-masing konsentrasi dipipet dan dimasukkan kedalam labu ukur $5 \mathrm{~mL}$, volume dicukupkan dengan metanol p.a hingga tanda batas.

Diambil masing-masing larutan sebanyak 1 $\mathrm{mL}$ dimasukkan kedalam tabung reaksi, ditambahkan dengan $2 \mathrm{~mL}$ larutan DPPH 0,08 $\mathrm{mM}$, kemudian di vorteks dan diinkubasi pada suhu kamar selama 30 menit dalam keadaan 
gelap. Larutan tersebut kemudian diukur pada panjang gelombang maksimum yang diperoleh.

\section{Penentuan \% Inhibisi Radikal Bebas DPPH}

Aktivitas penangkal radikal bebas DPPH dinyatakan sebagai \%inhibisi yang dapat dihitung menggunakan rumus sebagai berikut :

$$
\% \text { inhibisi }=1-\frac{\text { absorbansi larutan uji }}{\text { absorbansi kontrol }} \times 100 \%
$$

\section{Penentuan Nilai $\mathrm{IC}_{50}$ (Inhibitory Concentration)}

Konsentrasi sampel dan \%inhibisinya diplot masing-masing pada sumbu $\mathrm{x}$ dan $\mathrm{y}$ menggunakan persamaan regresi linear. Persamaan tersebut digunakan untuk menentukan nilai $\mathrm{IC}_{50}$ dari masing-masing sampel. Nilai y dinyatakan sebesar 50 dan nilai $\mathrm{x}$ yang akan diperoleh sebagai $\mathrm{IC}_{50}$.

\section{HASIL DAN PEMBAHASAN Ekstraksi}

Proses ekstraksi dari serbuk daun gedi hijau dilakukan dengan menggunakan metode maserasi. Tujuan digunakan metode maserasi, yaitu untuk menyari zat-zat aktif yang terkandung dalam simplisia daunn gedi. Pengadukan pada proses maserasi dilakukan bertujuan untuk meningkatkan kontak antar serbuk simplisia dengan pelarut sehingga zatzat aktif dalam serbuk simplisia banyak yang tersari dalam larutan penyari. Pelarut yang digunakan dalam penyarian zat aktif adalah pelarut etanol $96 \%$ yang bersifat polar. Penggunaan etanol sebagai pelarut dikarenakan etanol juga bersifat universal sehingga dapat menarik sebagian besar senyawa kimia yang terkandung di dalam simplisia (polar dan non polar) (Salamah, 2015).

Berdasarkan hasil ekstraksi, di peroleh berat ekstrak 13,75 gr dengan nilai rendemen
5,5\%. Dari hasil yang diperoleh, dapat dilihat bahwa hasil rendemen ekstrak daun gedi hijau yang diperoleh kecil. Hal ini menunjukan bahwa metode ekstraksi yang digunakan berpengaruh terhadap nilai rendemen yang diperoleh. Pada metode maserasi dilihat dari segi waktu, untuk memperoleh zat aktif yang lebih banyak dibutuhkan waktu dan proses yang lama karena ekstraksi ini tidak menggunakan bantuan panas. Faktor lain yang memungkinkan dapat mempengaruhi nilai rendemen yang dihasilkan, yaitu metode ekstraksi yang digunakan, ukuran partikel sampel, kondisi dan waktu penyimpanan.

\section{Uji Pendahuluan Aktivitas Penangkap Radikal Bebas}

Uji pendahuluan dilakukan untuk mengetahui ada atau tidaknya aktivitas penangkap radikal bebas dari ekstrak daun gedi hijau terhadap radikal bebas DPPH. Uji pendahuluan dilakukan dengan menggunakan metode Kromatografi Lapis Tipis (KLT), Fase gerak yang digunakan pada uji pendahuluan secara KLT yaitu n-heksana : kloroform p.a dengan perbandingan 1:2. Spot noda yang terbentuk dideteksi menggunakan sinar UV dengan panjang gelombang 245 dan $366 \mathrm{~nm}$ juga dilakukan untuk mengetahui spot yang dapat berfluoresensi (berpendar) sehingga dapat terlihat secara visual.
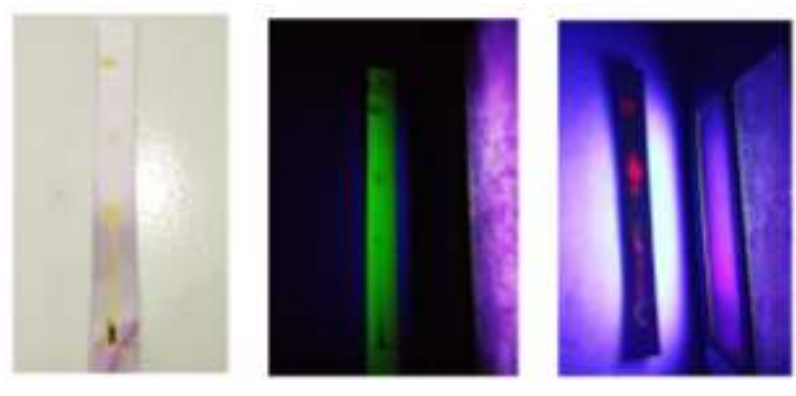
Gambar 1. Profil KLT hasil uji pendahuluan aktivitas penangkap radikal bebas menggunakan fase gerak n-heksana : kloroform p.a $(1: 2, \mathrm{v} / \mathrm{v})$. (a) telah disemprot dengan larutan DPPH 0,08 mM; (b) dilihat pada sinar UV 254; (c) dilihat pada sinar UV 366.

Hasil uji pendahuluan aktivitas penangkap radikal bebas pada Gambar 1, menunjukkan bahwa ekstrak daun gedi hijau mempunyai aktivitas penangkal radikal bebas DPPH. Hal ini dapat dilihat dari perubahan warna spot noda menjadi kuning dengan latar belakang ungu dan mempunyai intensitas warna yang kuat pada KLT setelah disemprot dengan larutan DPPH 0,08 mM. Interaksi senyawa penangkap radikal bebas pada ekstrak daun gedi hijau dengan DPPH, yaitu senyawa penangkap radikal bebas mentransfer elektron atau atom hidrogen pada DPPH sehingga mampu menetralkan karakter radikal bebas dari DPPH.

\section{Fraksinasi dan Uji aktivitas Penangkap Radikal Bebas}

Berdasarkan hasil KLT fraksi ekstrak daun gedi hijau yang telah disemprot dengan larutan DPPH 0,08 mM menghasilkan 5 fraksi aktif gabungan dari 12 fraksi pertama, dapat dilihat pada Tabel 1 dan Gambar 2.

Tabel 1. Fraksi dengan profil noda dan nilai Rf sama

\begin{tabular}{ccc}
\hline No & Fraksi (gabungan) & Fraksi aktif \\
\hline 1 & I dan II & I \\
2 & III dan IV & II \\
3 & V dan VI & III \\
4 & VII, VIII dan IX & IV \\
5 & X dan XI & V \\
\hline
\end{tabular}

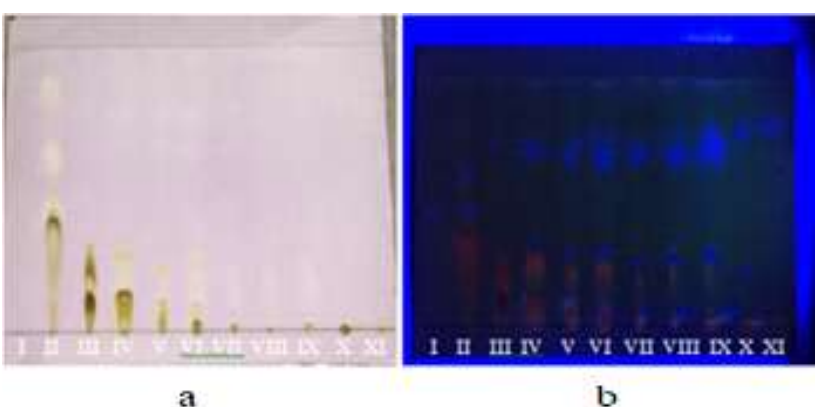

Gambar 2. profil KLT hasil fraksinasi ekstrak daun gedi hijau dengan menggunakan fase gerak n-heksana : kloroform p.a (6:12, v/v), dan disemprotkan dengan larutan DPPH 0,08 mM. (a) telah disemprot dengan larutan DPPH 0,08 mM; (b)dilihat pada sinar UV 366.

Dari hasil yang diperoleh, setiap fraksi gabungan memiliki beberapa spot noda yang terbentuk dapat dilihat pada Gambar 2. Komponen kimia yang terdapat dalam fraksi akan bergerak naik mengikuti fase gerak karena daya serap adsorben terhadap komponenkomponen kimia tidak sama sehingga komponen kimia dapat bergerak dengan jarak yang berbeda berdasarkan tingkat kepolarannya (Christian, 1994). Hal inilah yang menyebabkan terjadinya pemisahan-pemisahan komponen kimia dalam ekstrak akibat adanya interaksi antara fase diam (silika gel) dan fase gerak (eluen) sehingga menghasilkan noda.

\section{Penentuan Panjang Gelombang Maksimum} $\left(\lambda_{\text {maks }}\right)$

Tujuan dilakukan pengukuran pada panjang gelombang maksimum adalah perubahan absorban untuk setiap satuan konsentrasi adalah paling besar pada panjang gelombang maksimum, sehingga akan diperoleh kepekaan analisis yang maksimum. Hasil penelitian menunjukan bahwa panjang gelombang maksimum untuk pengukuran senyawa penangkap radikal bebas dengan metode peredaman DPPH adalah pada panjang 
gelombang $517 \mathrm{~nm}$ dimana serapan DPPH maksimum yang ditandai dengan adanya puncak dengan nilai absorbansi 0,706 .

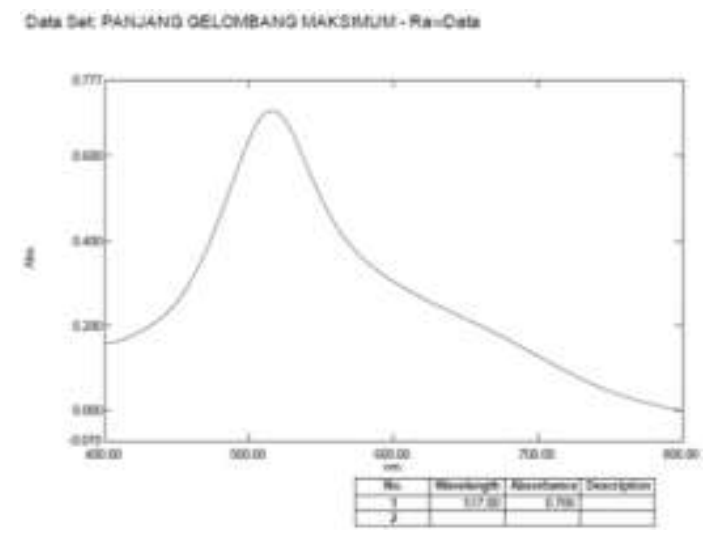

Gambar 3. Kurva Penentuan Panjang Gelombang Maksimum ( $\left.\lambda_{\text {maks }}\right)$ DPPH

\section{Uji Aktivitas Penangkal Radikal Bebas DPPH}

Pengujian aktivitas penangkap radikal bebas fraksi daun gedi hijau dilakukan dengan menggunakan metode DPPH (1,1-diphenil-2picrylhydarzyl). Pertimbangan dari metode tersebut karena metode DPPH merupakan metode yang relatif mudah, peka dan memerlukan sedikit sampel serta proses pengerjaannya cukup sederhana. Hasil pengujian dapat dilihat pada Tabel 2.

Tabel 2. Konsentrasi dan absorbansi dari masing-masing Fraksi dan Pembanding (Vitamin C)

\begin{tabular}{|c|c|c|c|c|c|}
\hline \multirow[t]{2}{*}{ No } & \multirow[t]{2}{*}{ Sampel } & \multirow[t]{2}{*}{ Konsentrasi } & \multicolumn{2}{|c|}{ Absorbansi } & \multirow[t]{2}{*}{ Rata-rata absorbansi \pm SD } \\
\hline & & & Pengulangan I & Pengulangan II & \\
\hline \multirow[t]{4}{*}{1} & Fraksi I & 15 & 0,586 & 0,579 & $0,582 \pm 0,0049$ \\
\hline & & 30 & 0,572 & 0,527 & $0,549 \pm 0,0318$ \\
\hline & & 60 & 0,475 & 0,469 & $0,472 \pm 0,0042$ \\
\hline & & 120 & 0,438 & 0,433 & $0,435 \pm 0,0035$ \\
\hline \multirow[t]{4}{*}{2} & Fraksi II & 15 & 0,647 & 0,630 & $0,638 \pm 0,0120$ \\
\hline & & 30 & 0,643 & 0,613 & $0,628 \pm 0,0212$ \\
\hline & & 60 & 0,640 & 0,596 & $0,618 \pm 0,0311$ \\
\hline & & 120 & 0,610 & 0,590 & $0,600 \pm 0,0141$ \\
\hline \multirow[t]{4}{*}{3} & Fraksi III & 15 & 0,624 & 0,617 & $0,620 \pm 0,0049$ \\
\hline & & 30 & 0,614 & 0,612 & $0,613 \pm 0,0014$ \\
\hline & & 60 & 0,579 & 0,558 & $0,568 \pm 0,0148$ \\
\hline & & 120 & 0,556 & 0,503 & $0,529 \pm 0,0374$ \\
\hline \multirow[t]{4}{*}{4} & Fraksi IV & 15 & 0,640 & 0,634 & $0,637 \pm 0,0042$ \\
\hline & & 30 & 0,637 & 0,607 & $0,622 \pm 0,0212$ \\
\hline & & 60 & 0,616 & 0,559 & $0,587 \pm 0,0403$ \\
\hline & & 120 & 0,556 & 0,462 & $0,509 \pm 0,0664$ \\
\hline \multirow[t]{4}{*}{5} & Fraksi V & 15 & 0,639 & 0,621 & $0,630 \pm 0,0127$ \\
\hline & & 30 & 0,628 & 0,616 & $0,622 \pm 0,0084$ \\
\hline & & 60 & 0,625 & 0,615 & $0,620 \pm 0,0070$ \\
\hline & & 120 & 0,623 & 0,608 & $0,615 \pm 0,0106$ \\
\hline \multirow[t]{4}{*}{6} & Vitamin C & 2 & 0,409 & 0,467 & $0,438 \pm 0,0410$ \\
\hline & & 4 & 0,246 & 0,401 & $0,323 \pm 0,1096$ \\
\hline & & 6 & 0,136 & 0,105 & $0,120 \pm 0,0219$ \\
\hline & & 8 & 0,103 & 0,096 & $0,099 \pm 0,0049$ \\
\hline
\end{tabular}

Pada metode ini, DPPH bertindak sebagai model radikal bebas yang akan berikatan dengan senyawa penangkap radikal bebas.
Pengukuran absorbansi dalam penelitian ini dilakukan panjang gelombang maksimum $\left(\lambda_{\text {maks }}\right)$ DPPH yang diperoleh, yaitu $517 \mathrm{~nm}$ 
dengan absorbansi sebesar 0,706. Pengujian dengan menggunakan spektrofotometer UV-Vis dilakukan untuk mengetahui absorbansi DPPH yang tersisa setelah ditambahkan sampel uji dengan berbagai konsentrasi. Jika suatu senyawa memiliki aktivitas sebagai penangkal radikal bebas, maka akan terjadi penurunan nilai absorbasi DPPH pada panjang gelombang maksimum $517 \mathrm{~nm}$.

Hasil yang diperoleh pada Tabel 2, menunjukan bahwa setiap sampel larutan uji mengalami penurunan nilai absorbansi ketika konsentrasi sampel uji semakin tinggi. Hal ini didukung dengan penelitian Salamah et al., (2015), yang menyatakan bahwa suatu senyawa yang memiliki aktivitas penangkapan radikal bebas akan mendonorkan atom hidrogennya untuk berikatan dengan DPPH membentuk DPPH tereduksi (DPPH-H). Reaksi radikal bebas DPPH dan senyawa penangkap radikal bebas dapat dilihat pada Gambar 3.

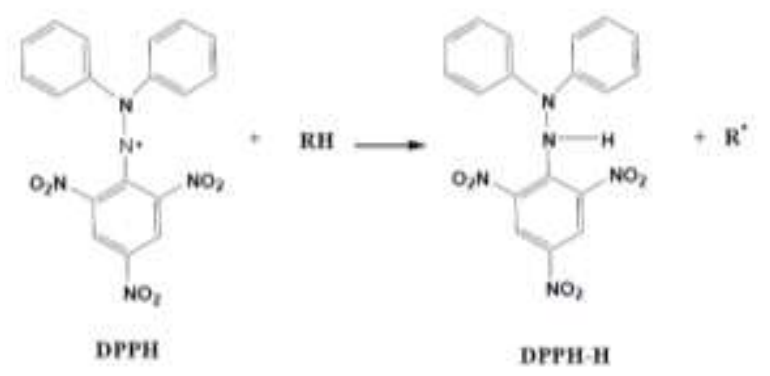

Gambar 3. Reaksi Radikal DPPH dan Antioksidan (Prakash, 2001).

\section{Penentuan \% Inhibisi Radikal Bebas DPPH}

Penentuan \% inhibisi atau persen perendaman radikal bebas digunakan untuk membandingkan aktivitas penangkapan radikal bebas DPPH larutan pembanding vitamin $\mathrm{C}$ dan larutan uji (Fraksi). Data hasil yang di peroleh pada gambar 4, menunjukkan adanya aktivitas peredaman radikal DPPH, yang dilihat dari adanya penurunan nilai absorbansi radikal DPPH yang disebabkan oleh larutan uji pada berbagai konsentrasi dan semakin meningkatnya nilai persen perendamam radikal bebas.

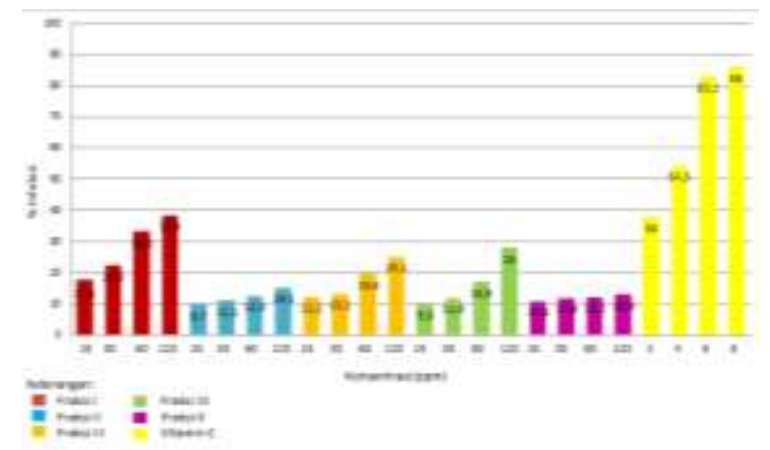

Gambar 4. Diagram \% Inhibisi Radikal Bebas DPPH dari tiap larutan uji dan pembanding.

\section{Penentuan Nilai $\mathbf{I C}_{\mathbf{5 0}}$}

Nilai IC $_{50}$ didefinisikan sebagai besarnya konsentrasi senyawa uji yang dapat meredam radikal bebas sebanyak 50\%. Semakin kecil nilai $\mathrm{IC}_{50}$ maka aktivitas peredaman radikal bebas semakin tinggi. Nilai $\mathrm{IC}_{50}$ diperoleh dari suatu persamaan regresi linier yang menyatakan hubungan antara konsentrasi senyawa uji dengan persen penangkapan radikal bebas.

Tabel 3. Hasil Perhitungan Nilai $\mathrm{IC}_{50}$ dari masing-masing fraksi dan pembanding.

\begin{tabular}{ccccc}
\hline No & Sampel & Persamaan Regresi & ${\text { Nilai } \mathrm{IC}_{50}(\mu \mathrm{g} / \mathrm{mL})}^{\text {Kategori }}$ \\
\hline 1 & Fraksi I & $\mathrm{y}=0,195 \mathrm{x}+16,909$ & 169,69 & Lemah \\
2 & Fraksi II & $\mathrm{y}=0,0492 \mathrm{x}+9,3348$ & 825,78 & Sangat Lemah \\
3 & Fraksi III & $\mathrm{y}=0,1274 \mathrm{x}+10,361$ & 311,13 & Sangat Lemah \\
4 & Fraksi IV & $\mathrm{y}=0,175 \mathrm{x}+6,8087$ & 246,80 & Sangat Lemah \\
5 & Fraksi V & $\mathrm{y}=0,017 \mathrm{x}+10,991$ & 2294,64 & Tidak Aktif \\
6 & Vitamin C & $\mathrm{y}=8,64 \mathrm{x}+22,15$ & 3,22 & Sangat Kuat \\
\hline
\end{tabular}


Senyawa dikatakan memiliki aktivitas penangkap radikal bebas sangat kuat apabila nilai $\mathrm{IC}_{50}$ kurang dari $50 \mu \mathrm{g} / \mathrm{mL}$, kuat apabila nilai $\mathrm{IC}_{50}$ antara $50-100 \mu \mathrm{g} / \mathrm{mL}$, sedang apabila nilai $\mathrm{IC}_{50}$ antara $100-150 \mu \mathrm{g} / \mathrm{mL}$, dan lemah apabila nilai $\mathrm{IC}_{50}$ antara $150-200 \mu \mathrm{g} / \mathrm{mL}$. Nilai $\mathrm{IC}_{50} \quad 200-1000 \mu \mathrm{g} / \mathrm{mL}$ dinyatakan masih berpotensi sebagai senyawa penangkap radikal bebas, namun memiliki aktivitas penangkap radikal bebas yang sangat lemah (Molyneux, 2004).

Dari hasil perhitungan nilai $\mathrm{IC}_{50}$ pada Tabel 3, fraksi I memiliki aktivitas sebagai penangkap radikal bebas, namun bersifat lemah. Sedangkan fraksi II, III, dan IV memiliki aktivitas penangkap radikal bebas yang bersifat sangat lemah, Sedangkan, pada fraksi V tidak memiliki aktivitas sebagai senyawa penangkap radikal bebas, karena memiliki nilai $\mathrm{IC}_{50}$ yang sangat besar.

Vitamin C sebagai kontrol positif mempunyai aktivitas sebagai penangkap radikal bebas yang sangat kuat karena memiliki nilai $\mathrm{IC}_{50}$ kurang dari $50 \mu \mathrm{g} / \mathrm{mL}$. Perbandingan nilai $\mathrm{IC}_{50}$ dari tiap fraksi ekstrak daun gedi hijau dengan nilai $\mathrm{IC}_{50}$ dari vitamin $\mathrm{C}$ menunjukkan adanya perbedaan aktivitas penangkap radikal bebas. Perbedaan ini disebabkan karena vitamin C mempunyai gugus hidroksil bebas yang bertindak sebagai penangkap radikal bebas.

\section{KESIMPULAN}

Dari hasil penelitian yang diperoleh Fraksi I bersifat sebagai penangkap radikal bebas, namun aktivitasnya bersifat lemah, sedangkan fraksi II, III, dan IV dapat bersifat sebagai penangkap radikal bebas, namun memiliki aktivitas penangkap radikal bebas yang sangat lemah, hal ini dikarenakan nilai $\mathrm{IC}_{50}$ (Inhibitory Concentration), dari tiap fraksi yang diperoleh cukup besar. Pada fraksi V, tidak memiliki aktivitas sebagai penangkap radikal bebas, karena memiliki nilai $\mathrm{IC}_{50}$ yang sangat besar. Oleh sebab itu, penelitian ini tidak direkomendasikan sebagai senyawa penangkap radikal bebas.

\section{DAFTAR PUSTAKA}

Burda, S., and Oleszek, W. 2001. Antioxidant and Antiradical Activities of Flavanoid. Journal of Agricultural and Food Chemistry. 49: 2774-2779.

Christian, Gary D. 1994. Analytical Chemistry. Fifth Edition. University of Washington. John Wiley \& Sons, USA.

Hodgson, J.M., and Kevin D.C., 2006, Review Dietary flavonoids:effects on endothelial function and blood pressure, Journal Science Food Agriculture, 86:2492-2498.

Mamahit, L.P., dan Soekarno, N. H. 2010. Satu senyawa organic yang diisolasidari daun gedi (Albemoschus manihot L. Medik) Asal Sulawesi utara. Chemistry Progress. Vol. 3 No. 1, P. 45.

Molyneux, P. 2004. The Use of The Stable Free Radical Diphenylpicryl-hydrazyl (DPPH) for Estimating Antioxidant Activity. Songklanakarin J. Sci. Technol. 26 (2): 211-219.

Prakash, A. 2001. Antioxidant Activity, Medallion Laboratories Analytical Progress. vol. 19, No. 2.

Salamah, N., Widyasari, E. 2015. Aktivitas Antioksidan Ekstrak Metanol Daun Kelengkeng (Euphoria longan (L) Steud.) dengan metode Penangkapan Radikal 2,2-difenil-1-pikrilhidrazil. Pharmaçiana, Vol. 5 (1): 25-34. 


\section{PHARMACON- PROGRAM STUDI FARMASI, FMIPA, UNIVERSITAS SAM RATULANGI,}

Volume 8 Nomor 1 Februari 2019

Sudewi, S., Lolo, W., Rifai, Y., Rante, H. 2017. Analisis Finger Print Tanaman Gedi (Abelmoschus Manihot L.) dengan Metode Spektroskopi FTIR dan Kemometrik serta Aktivitas Penangkal Radikal Bebas. Laporan Penelitian Kemenristekdikti 2017. LPPM UNSRAT. 